$\begin{array}{rr}\text { FURNAL } & \\ \text { FITPATOLOGI } & \text { Volume } 12, \text { Nomor 5, September } 2016 \\ \text { I N DON ES IA } & \text { Halaman } 159-167 \\ \text { ISSN: } 0215-7950 & \text { DOI: } 10.14692 / \text { jfi. } 12.5 .159\end{array}$

\title{
Penekanan Perkembangan Penyakit Bercak Ungu pada Bawang Merah oleh Cendawan Mikoriza Arbuskula
}

\author{
Suppressing of Purple Blotch Disease Development on Shallot by \\ Arbuscular Mycorrhizal Fungi
}

\author{
Marlina Puspita Sari*, Bambang Hadisutrisno, Suryanti \\ Universitas Gadjah Mada, Yogyakarta 55281
}

\begin{abstract}
ABSTRAK
Cendawan mikoriza arbuskula (CMA) diketahui meningkatkan pertumbuhan tanaman bawang merah (Allium cepa var. aggregatum) dan membantu meningkatkan ketahanan tanaman terhadap gangguan penyakit. Penelitian ini bertujuan mengetahui peran CMA dalam menekan perkembangan penyakit bercak ungu yang disebabkan oleh Alternaria sp. pada pertanaman bawang merah di Dusun Gowok, Caturtunggal, Sleman, Yogyakarta. Perlakuan inokulasi CMA pada tanaman bawang merah yang dipupuk atau yang tidak dipupuk N, P, dan K menyebabkan tinggi tanaman dan jumlah daun yang lebih besar dibandingkan dengan perlakuan tanpa inokulasi CMA. Intensitas dan laju perkembangan penyakit bercak ungu pada tanaman bawang merah yang diinokulasi CMA lebih rendah dibandingkan dengan kontrol maupun tanaman yang diberi perlakuan fungisida kimia. Hasil tersebut menunjukkan bahwa CMA selain berperan sebagai pupuk hayati juga berpotensi sebagai agens pengendali hayati.
\end{abstract}

Kata kunci: agens pengendali hayati, Alternaria porri, ketahanan tanaman.

\begin{abstract}
Arbuscular mycorrhizal fungi (AMF) is known to improve the growth of shallot (Allium cepa var. aggregatum) and strengthen the resistance of plants toward disease infection. This research aimed to find out the roles of AMF in suppressing the development of purple blotch disease caused by Alternaria sp. on shallot in Caturtunggal, Sleman, Yogyakarta. Inoculation of AMF either on fertilization of N, P, K or without fertilization treatment resulted on higher plant height and number of leaves compared to those without AMF inoculation. The plant inoculated with AMF had lower purple blotch disease intensity and disease progression than control and fungicide treatment. The result showed that AMF, in addition to act as the bio-fertilizer, is a potential to be a biocontrol agent.
\end{abstract}

Key words: Alternaria porri, biological control agents, plant resistance

*Alamat penulis korespondensi: Program Studi Fitopatologi, Fakultas Pertanian, Universitas Gadjah Mada. Jalan Flora 1 Bulaksumur, Depok Sleman ,Yogyakarta 55281.

Tel: 0274-563062,Faks: 0274-563062,Surel: marlina.puspita.s@mail.ugm.ac.id 


\section{PENDAHULUAN}

Bawang merah merupakan komoditas hortikultura unggulan Indonesia. Dalam proses budi dayanya masih dijumpai berbagai kendala, di antaranya ialah gangguan penyakit bercak ungu oleh Alternaria porri yang berpotensi menimbulkan kehilangan. Upaya pengendalian penyakit bercak ungu ini masih ditekankan pada penggunaan fungisida kimia, padahal penggunaan fungisida kimia secara terusmenerus berdampak negatif bagi lingkungan.

Saat ini sedang banyak dikembangkan dan diteliti pupuk hayati yang-mengandung cendawan mikoriza arbuskula (CMA) berpotensi sebagai agens pengendali hayati. Bawang merah memiliki sistem perakaran dangkal dan kasar yang bergantung pada CMA. Apabila tanaman ini tanpa CMA kondisinya akan lemah dan mudah mendapat gangguan penyakit seperti bercak ungu (Raduica et al. 2008). CMA yang bersimbiosis dengan akar tanaman mampu meningkatkan laju pertumbuhan vegetatif dan produksi tanaman. Whipps (2004) melaporkan bahwa CMA selain mampu meningkatkan pertumbuhan tanaman juga berpotensi sebagai agens pengendali hayati melalui berbagai mekanisme khususnya untuk patogen tular tanah seperti Fusarium moniliforme, F. oxysporum, Rhizoctonia solani, dan beberapa spesies Phytophthora. Penelitian mengenai peran CMA dalam menekan perkembangan penyakit yang menginfeksi daun saat ini menunjukkan hasil yang bervariasi. Swastiningrum (2015) membuktikan bahwa CMA dapat mempersempit lebar bukaan stomata pada tebu, hal ini semakin memperkuat potensi CMA sebagai agens pengendali hayati untuk patogen yang penetrasinya melalui stomata seperti $A$. porri. Pengujian terhadap peran CMA dalam menekan perkembangan penyakit bercak ungu pada bawang merah perlu dilakukan sebagai langkah awal dalam pengendalian yang ramah lingkungan.

\section{BAHAN DAN METODE}

Penelitian dilaksanakan di lahan dusun Gowok, Caturtunggal, Depok, Sleman, Yogyakarta (113 m dpl) dan di laboratorium pada bulan April-Agustus 2015. Pupuk hayati mikoriza yang digunakan dalam penelitian merupakan produksi gapoktan Tani Makmur yang bekerjasama dengan Laboratorium Pengamatan Hama dan Penyakit Temanggung dan Laboratorium Mikologi Pertanian Fakultas Pertanian Universitas Gadjah Mada. Pupuk hayati dikemas dalam zeolit sebagai medium pembawa dengan kerapatan spora CMA sebanyak 11 spora $\mathrm{g}^{-1}$.

\section{Plot Perlakuan}

Lahan yang digunakan ialah lahan bekas sawah yang tidak dilakukan sterilisasi sebelum digunakan agar meminimalkan keberadaan CMA indigenus. Lahan diolah sesuai dengan standar agronomi dan dibuat bedengan lebar $120 \mathrm{~cm}$, panjang $200 \mathrm{~cm}$, dan tinggi $25 \mathrm{~cm}$. Bedengan-bedengan ini digunakan sebagai plot perlakuan dengan empat blok ulangan. Jarak antar bedengan dalam satu ulangan ialah $50 \mathrm{~cm}$, sedangkan jarak bedengan antara ulangan ialah $70 \mathrm{~cm}$.

\section{Populasi CMA pada Lahan sebelum Penanaman}

Sebelum dilakukan penanaman diambil sampel tanah dari lahan sebanyak $100 \mathrm{~g}$ per blok ulangan untuk menentukan populasi CMA indigenus pada lahan penelitian. Populasi spora diamati dengan metode ekstraksi spora mengikuti metode Daniels dan Skipper (1982), yaitu $100 \mathrm{~g}$ tanah dimasukkan dalam gelas piala yang berisi $500 \mathrm{~mL}$ air dan diaduk selama 15 menit, kemudian suspensi disaring dengan saringan $75 \mu \mathrm{m}$. Suspensi hasil penyaringan diaduk kemudian disaring kembali dengan saringan $54 \mu \mathrm{m}$. Suspensi berisi spora yang sudah disaring kemudian disentrifugasi selama 5 menit dengan kecepatan 2000 rpm. Cairan supernatan dibuang lalu ditambahkan larutan gula $65 \%$ dan dihomogenkan dengan vorteks. Tabung disentrifugasi selama 2 menit dengan kecepatan $2000 \mathrm{rpm}$. Cairan supernatan disaring dengan saringan $54 \mu \mathrm{m}$, saringan dibilas dengan air untuk menghilangkan larutan gula, kemudian spora ditampung untuk diamati kerapatan populasinya dengan mikroskop binokuler. 


\section{Penanaman Bawang Merah dan Inokulasi CMA}

Bawang merah varietas Biru-varietas rentan terhadap penyakit bercak unguditanam dengan jarak tanam $10 \mathrm{~cm} \times 20 \mathrm{~cm}$. Pupuk dasar yang diberikan ialah pupuk kompos $\left(5000 \mathrm{~kg} \mathrm{ha}^{-1}\right)$ dan SP-36 $\left(200 \mathrm{~kg} \mathrm{ha}^{-1}\right)$. Pupuk dasar diberikan 3 hari sebelum penanaman (Suwandi et al. 1992). Saat penanaman, tanaman diberi pupuk hayati CMA sebanyak $10 \mathrm{~g}$ per lubang tanam. Pemupukan susulan pertama dengan pupuk $\mathrm{N}\left(75 \mathrm{~kg} \mathrm{ha}^{-1}\right)$ dan pupuk $\mathrm{K}\left(25 \mathrm{~kg} \mathrm{ha}^{-1}\right)$

dilakukan 15 hari setelah tanam (HST). Pemupukan susulan kedua dilakukan 30 HST dengan pemberian pupuk $\mathrm{N}\left(75 \mathrm{~kg} \mathrm{ha}^{-1}\right)$ dan $\mathrm{K}$ $\left(25 \mathrm{~kg} \mathrm{ha}^{-1}\right)$ (Hidayat dan Rosliani 1996).

Aplikasi fungisida berbahan aktif mankozeb dengan konsentrasi larutan $2 \mathrm{~g} \mathrm{~L}^{-1}$ dan dosis 500-1000 L larutan ha ${ }^{-1}$ dilakukan setiap minggu dimulai 3 minggu setelah tanam sampai seminggu sebelum panen. Pemeliharaan yang dilakukan meliputi penyiangan, penyiraman, dan penggemburan tanah. Pengamatan dilakukan setiap minggu sampai tanaman dipanen (umur 8 minggu) yang dimulai sejak tanaman berumur 1 minggu.

\section{Pengamatan}

Peubah yang diamati meliputi tinggi tanaman, jumlah daun, intensitas, dan laju perkembangan penyakit bercak ungu. Pengamatan perkembangan penyakit bercak ungu dimulai sejak muncul gejala dan diamati setiap minggu selama 8 minggu dengan menggunakan sistem skoring, yaitu 1, 1-20\% luas daun terserang; 2, 21-40\% luas daun terserang; 3, 41-60\% luas daun terserang; 4, 61-80\% luas daun terserang; 5, 81-100\% luas daun terserang (Soedomo 2006).

Intensitas penyakit dihitung menggunakan rumus:

$$
\mathrm{IP}=\frac{\Sigma \mathrm{v}_{\mathrm{i}} \times \mathrm{n}_{\mathrm{i}}}{\mathrm{Z} \times \mathrm{N}} \times 100 \%, \text { dengan }
$$

IP, intensitas penyakit $(\%) ; n_{i}$, jumlah tanaman pada kategori serangan ke-i; $\mathrm{N}$, jumlah tanaman yang diamati; $v_{i}$, nilai skor kategori serangan ke-i; Z, nilai skor kategori serangan tertinggi.
Laju perkembangan penyakit bercak ungu dihitung dengan rumus epidemiologi van der Plank (1963). Infeksi CMA pada akar bawang merah diamati saat tanaman berumur 5 dan 8 minggu (saat panen). Sebanyak 15 sampel akar tanaman diambil dari masing-masing plot perlakuan. Akar dicuci dengan air mengalir lalu dipotong dengan ukuran $1 \mathrm{~cm}$ kemudian diwarnai dan dianalisis mengikuti Kormanik dan McGraw (1982).

Potongan akar diamati di atas kaca objek menggunakan mikroskop. Setiap kaca objek berisi 25 potongan akar. Akar dinyatakan terinfeksi apabila ditemukan minimal salah satu dari organ CMA (hifa, vesikula atau arbuskula) di dalam jaringan akar. Persentase infeksi (\%) akar dihitung dengan rumus:

Persentase infeksi $=\frac{\sum \text { akar terinfeksi }}{\sum \text { akar yang diamati }} \times 100 \%$

\section{Rancangan Percobaan dan Analisis Data}

Penelitian ini disusun dalam rancangan acak kelompok faktorial dengan dua faktor, yaitu pemupukan dan pemberian CMA, masing-masing terdiri atas 2 taraf. Faktor pertama ialah tanpa dipupuk (N0) dan dipupuk $\mathrm{N}, \mathrm{P}, \mathrm{K}(\mathrm{N} 1)$. Faktor kedua ialah pengendalian penyakit dengan 3 taraf, yaitu kontrol (P0), inokulasi CMA (P1), aplikasi fungisida kimia (P2). Jadi terdapat 6 kombinasi perlakuan, masing-masing perlakuan memiliki 4 blok ulangan. Data yang diperoleh dari masingmasing peubah pengamatan dianalisis menggunakan analisis varian, apabila terdapat beda nyata dilanjutkan dengan uji jarak berganda Duncan pada $\alpha$ 5\%.

\section{HASIL}

\section{Populasi CMA pada Lahan Penelitian}

Populasi spora CMA di lahan penelitian ialah 0.92 spora $\mathrm{g}^{-1}$ tanah. Hal ini menunjukkan bahwa populasi CMA indigenus pada lahan penelitian sangat rendah.

\section{Tinggi Tanaman dan Jumlah Daun}

Hasil analisis data tinggi tanaman dan jumlah daun menunjukkan tidak terdapat interaksi antara faktor pemupukan N, P, 
dan $\mathrm{K}$ dengan faktor pengendalian penyakit sehingga kolaborasi antara kedua faktor tidak berpengaruh nyata terhadap pertumbuhan bawang merah (Tabel 1). Tinggi tanaman dan jumlah daun bawang merah dengan pemupukan $\mathrm{N}$, $\mathrm{P}$, dan $\mathrm{K}$ lebih tinggi dan berbeda nyata dibandingkan dengan tanaman tanpa pemupukan N, P, dan K. Pada faktor yang kedua, bawang merah yang diinokulasi CMA memiliki tinggi tanaman dan jumlah daun tertinggi dan berbeda nyata dibandingkan dengan tanaman kontrol namun tidak berbeda nyata dengan tanaman yang diaplikasi dengan fungisida kimia. Hal ini menunjukkan bahwa bawang merah dapat meningkat pertumbuhannya melalui pemupukan $\mathrm{N}, \mathrm{P}$, dan $\mathrm{K}$ atau dengan inokulasi CMA saja.

\section{Intensitas dan Laju Perkembangan Penyakit Bercak Ungu}

Gejala penyakit bercak ungu mulai terlihat ketika bawang merah berumur 4 minggu. Berdasarkan hasil analisis data intensitas penyakit tidak terdapat interaksi antara kedua faktor yang diujikan (Tabel 1). Bawang merah yang dipupuk $\mathrm{N}, \mathrm{P}$, dan $\mathrm{K}$ menunjukkan intensitas penyakit yang lebih rendah dibandingkan dengan yang tidak dipupuk, tetapi tidak berbeda nyata sehingga pemupukan $\mathrm{N}$, $\mathrm{P}$, dan $\mathrm{K}$ tidak berpengaruh terhadap persentase intensitas penyakit bercak ungu. Pada faktor pengendalian penyakit, bawang merah yang diinokulasi CMA memiliki intensitas penyakit bercak ungu yang lebih rendah dan berbeda nyata dibandingkan dengan perlakuan kontrol maupun perlakuan fungisida kimia, sedangkan persentase intensitas penyakit antara perlakuan kontrol dengan perlakuan aplikasi fungisida kimia tidak berbeda nyata. Hal ini menunjukkan bahwa inokulasi CMA berperan utama dalam menekan intesitas penyakit bercak ungu pada bawang merah.

Perhitungan laju perkembangan penyakit bercak ungu menunjukkan bahwa laju perkembangan penyakit bercak ungu tertinggi dijumpai pada perlakuan NOP0 (kontrol dan tanpa pemupukan N, P, dan K). Laju perkembangan penyakit yang paling rendah dijumpai pada perlakuan dengan inokulasi CMA dan pemupukan $\mathrm{N}$, $\mathrm{P}$, dan $\mathrm{K}$ (N1P1), yaitu sebesar 0.127 per unit per hari. Pada perlakuan dengan aplikasi CMA tanpa pemupukan $\mathrm{N}, \mathrm{P}$, dan $\mathrm{K}$ (N0P1) juga menunjukkan laju perkembangan penyakit yang rendah, yaitu 0.140 per unit per hari, lebih rendah dibandingkan dengan tanaman yang diperlakukan dengan fungisida kimia dan tanpa pemupukan N, P, dan K (NOP2) (Tabel2).

\section{Infeksi CMA pada Perakaran Bawang Merah}

Persentase infeksi CMA pada perakaran bawang merah yang diinokulasi dengan CMA dan dipupuk $\mathrm{N}$, $\mathrm{P}$, dan $\mathrm{K}$ maupun tanpa dipupuk menunjukkan nilai yang tinggi

Tabel 1 Tinggi tanaman, jumlah daun, dan intensitas penyakit bercak ungu di tanaman bawang merah pada pengamatan minggu ke-7

\begin{tabular}{lccc}
\hline Perlakuan & $\begin{array}{c}\text { Tinggi tanaman } \\
(\mathrm{cm})\end{array}$ & Jumlah daun & $\begin{array}{c}\text { Intensitas penyakit } \\
(\%)^{\mathrm{a}}\end{array}$ \\
\hline Pemupukan N, P, dan K & $31.61 \mathrm{~b}$ & $35.85 \mathrm{~b}$ & $37.45 \mathrm{a}$ \\
$\quad$ Tanpa dipupuk (N0) & $39.10 \mathrm{a}$ & $43.53 \mathrm{a}$ & $30.25 \mathrm{a}$ \\
Dipupuk (N1) & & & \\
Pengendalian penyakit & $32.86 \mathrm{~b}$ & $36.45 \mathrm{~b}$ & $44.85 \mathrm{a}$ \\
Kontrol (P0) & $37.86 \mathrm{a}$ & $42.89 \mathrm{a}$ & $21.87 \mathrm{~b}$ \\
CMA (P1) & $35.34 \mathrm{ab}$ & $39.73 \mathrm{ab}$ & $34.82 \mathrm{a}$ \\
Fungisida (P2) &
\end{tabular}

${ }^{a}$ Data ditransformasi menggunakan Arcsin $\sqrt{ }(\mathrm{IP} / 100) \times 180 / \pi$.

Angka yang diikuti huruf yang sama pada baris atau kolom yang sama tidak berbeda nyata berdasarkan uji jarak berganda Duncan pada $\alpha$ 5\%. 
Tabel 2 Laju perkembangan penyakit bercak ungu pada bawang merah per unit per hari

\begin{tabular}{lc}
\hline Perlakuan & $\begin{array}{c}\text { Laju perkembangan penyakit } \\
\text { (per unit per hari) }\end{array}$ \\
\hline Tanpa pemupukan N, P, dan K & 0.165 \\
Kontrol (N0P0) & 0.140 \\
Diinokulasi CMA (N0P1) & 0.149 \\
Diaplikasi fungisida kimia (N0P2) & \\
Dengan pemupukan N, P, dan K & 0.153 \\
Kontrol (N1P0) & 0.127 \\
Diinokulasi CMA (N1P1) & 0.150 \\
Diaplikasi fungisida kimia (N1P2) & \\
\hline
\end{tabular}

baik pada umur 5 dan 8 minggu. Pada umur 8 minggu persentase infeksi CMA pada bawang merah yang diinokulasi CMA sudah melebihi 90\% (Gambar 1). Pada bawang merah tanpa inokulasi CMA (perlakuan N0P0, N0P2, N1P0, dan N1P3) tampak terdapat akar yang terinfeksi CMA akan tetapi persentasenya sangat rendah dan berbeda nyata dengan persentase infeksi pada bawang merah yang diinokulasi CMA. Pengaruh nyata pada pertumbuhan dan penekanan perkembangan penyakit bercak ungu merupakan pengaruh dari inokulasi CMA, terlihat dari tingginya persentase infeksi CMA pada perakaran yang diinokulasi CMA baik dipupuk dengan N, P, dan $\mathrm{K}$ maupun tanpa dipupuk (Gambar 1). Hasil pengamatan infeksi CMA pada akar bawang merah ditemukan struktur CMA berupa vesikula, arbuskula dan hifa di dalam jaringan akar yang mengindikasi adanya infeksi CMA pada akar tersebut (Gambar 2).

\section{PEMBAHASAN}

CMA merupakan sumber daya hayati potensial yang dapat ditemukan pada berbagai ekosistem di alam (Wang dan Qui 2006). Populasi CMA indigenus di lahan masih tergolong rendah, yaitu 10 spora $\mathrm{g}^{-1}$ tanah bila dibandingkan dengan rekomendasi dari Kementan sehingga inokulasi CMA pada saat penanaman sangat dianjurkan untuk dilakukan. Inokulasi CMA baik pada skala rumah kaca maupun di lahan mampu meningkatkan pertumbuhan tanaman (Menge dan Timmer 1982). Pada kondisi tanah yang steril, inokulasi CMA pada tebu dapat meningkatkan pertumbuhan dan kesehatan tebu (Ismayanti et al. 2013). Hal ini menunjukkan bahwa CMA dapat berperan secara mandiri dalam meningkatkan pertumbuhan dan kesehatan tanaman tanpa adanya pengaruh mikroorganisme rizosfer maupun endofit yang ada di dalam tanah.

Pada penelitian ini diketahui bahwa inokulasi CMA di lahan dapat meningkatkan pertumbuhan bawang merah. Hal ini dikarenakan CMA dapat meningkatkan kemampuan bawang merah dalam menyerap air dan unsur hara yang sangat diperlukan dalam masa awal pertumbuhan tanaman (Goltapeh et al. 2008). Bawang merah memiliki perakaran yang dangkal dan kasar sehingga pupuk N, P, dan K yang diaplikasikan di sekitar perakaran kurang terjangkau oleh perakaran bawang merah meskipun jumlah yang diberikan sudah sesuai dosis atau bahkan sudah berlebih (Sumiati dan Gunawan 2006), sehingga keberadaan infestasi CMA pada perakaran bawang merah sangat membantu penyerapan unsur hara khususnya unsur $\mathrm{P}$ yang dibutuhkan oleh tanaman.

Penggunaan zeolit sebagai medium pembawa CMA pada penelitian ini tidak memengaruhi pertumbuhan maupun kesehatan tanaman karena hanya sebagai bahan pembawa. Zeolit yang digunakan tidak diaktivasi dengan perlakuan khusus sehingga tidak mengandung bahan-bahan yang diperlukan oleh tanaman dan memiliki sterilitas yang tinggi. Sesuai dengan penelitian Bondansari dan Susilo (2011), zeolit secara mandiri 


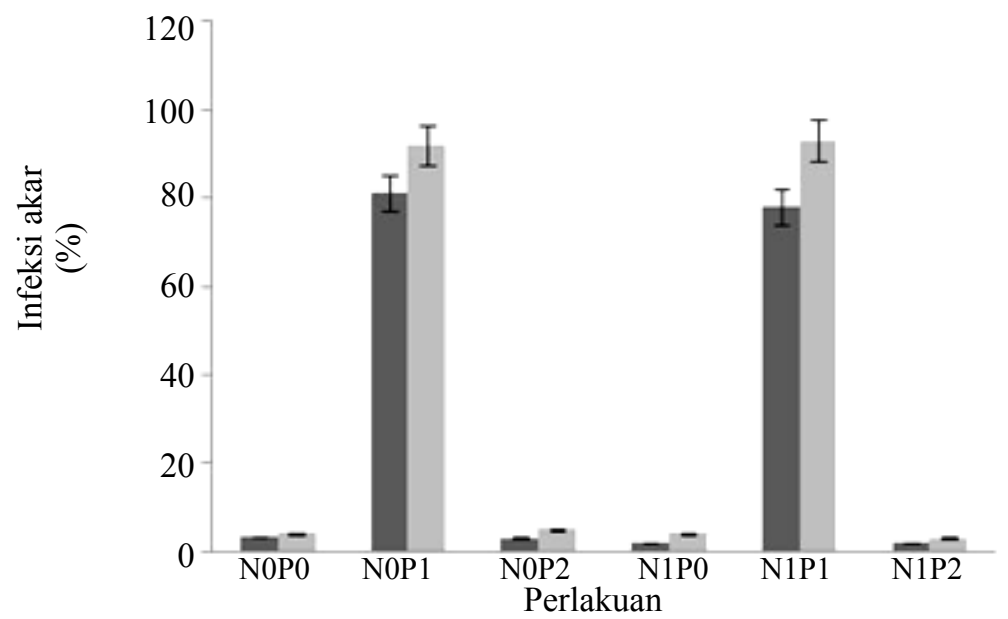

Gambar 1 Infeksi CMA pada akar bawang umur 5 (घ) dan 8 ( $匚$ ) minggu. N0P0, tanpa inokulasi CMA dan tanpa pemupukan N, P, dan K; N0P1, diinokulasi CMA dan tanpa pemupukan N, $\mathrm{P}$, dan K; N0P2, diaplikasi fungisida kimia dan tanpa pemupukan N, P, dan K; N1P0, tanpa inokulasi CMA dan dengan pemupukan N, P, dan K; N1P1, diinokulasi CMA dan dengan pemupukan N, P, dan K; N1P2, diaplikasi fungisida kimia dan dengan pemupukan N, P, dan K.
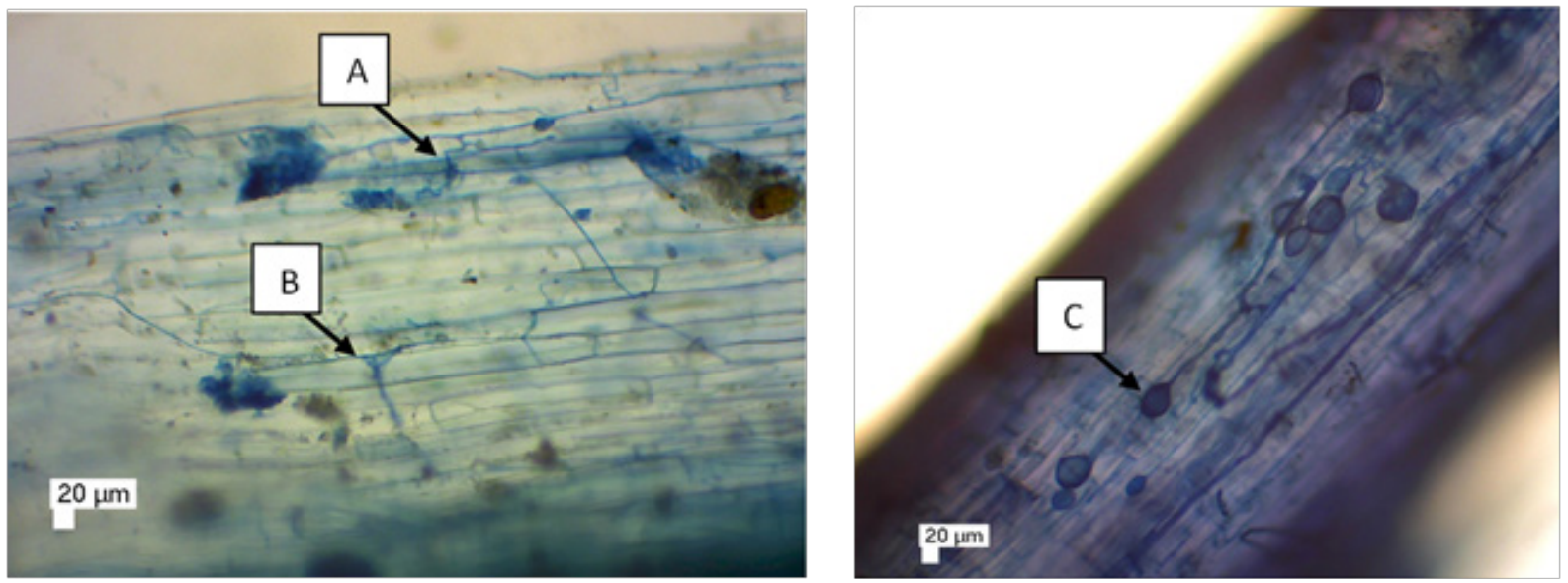

Gambar 2 Infeksi CMA pada akar bawang merah. A, Arbuskula; B, Hifa; C, Vesikula.

tidak berpengaruh dalam meningkatkan pertumbuhan dan produksi tanaman.

Persentase infeksi CMA yang tinggi pada perakaran bawang merah yang diinokulasi CMA menunjukkan bahwa inokulum CMA yang digunakan dalam penelitian ini merupakan inokulum yang masih baik dan infektif. Menurut Brundrett et al. (1997), di akar CMA akan membentuk struktur berupa vesikula dan arbuskula. Vesikula merupakan pembengkakan hifa internal yang berbentuk bulat telur serta berisi banyak senyawa lemak, sehingga dapat berfungsi sebagai organ penyimpanan cadangan makanan. Arbuskula merupakan hifa bercabang halus atau percabangan dari hifa yang dibentuk oleh percabangan dikotomi yang berulang-ulang, sehingga menyerupai pohon dari dalam sel inang tanaman. Arbuskula berfungsi sebagai penyuplai unsur hara bagi CMA dan tanaman inang. Akar yang terinfeksi CMA juga akan menghasilkan hifa internal, hifa eksternal dan spora (Anas dan Tampubolon 2004). Hifa eksternal CMA mampu meningkatkan penyerapan ion fosfat terlarut dalam bentuk $\mathrm{P}$ anorganik dan organik di dalam tanah sehingga semakin tinggi persentase infeksi CMA maka pertumbuhan tanaman akan semakin baik (Artursson et al. 2006).

Potensi CMA dalam menekan perkembangan penyakit terlihat dari intensitas penyakit bercak ungu dan nilai laju per- 
kembangan penyakit yang lebih rendah dibandingkan dengan perlakuan lain. Peran CMA terhadap kesehatan tanaman telah banyak diteliti namun perannya dalam pengendalian penyakit yang menginfeksi daun masih dalam tahap penelitian dan menunjukkan hasil yang bervariasi (Gernns et al. 2001), tanaman yang diinokulasi CMA cenderung lebih tahan terhadap patogen tipe nekrotrof (Fritz et al. 2006; De La Noval et al. 2007). Cendawan A. porri penyebab bercak ungu merupakan cendawan yang bersifat nekrotrofik, yaitu cendawan yang hidup dan berkembang pada sisa-sisa tanaman yang mati, dan apabila kondisi tanaman lemah, karena kekurangan unsur hara maupun cekaman lainnya maka dapat menyerang dan menimbulkan kerugian ekonomi (Woudenberg et al. 2014). Teknik pengendalian yang aman dan efektif untuk tipe patogen nekrotrof ialah dengan meningkatkan ketahanan alami yang dimiliki oleh tanaman yang dapat diperoleh ketika tanaman berada dalam kondisi prima (Ficke et al. 2002).

Kemampuan CMA dalam menekan intensitas dan perkembangan penyakit bercak ungu berkaitan erat dengan kemampuan CMA dalam meningkatkan pertumbuhan tanaman (Yu et al. 2001). Tanaman yang diinokulasi CMA lebih efisien dalam menggunakan fosfat yang tidak terlarut dalam tanah dibandingkan dengan tanaman yang tidak diinokulasi dengan CMA (Artursson et al. 2006). Mikronutrisi seperti seng $(\mathrm{Zn})$, tembaga $(\mathrm{Cu})$, sulfur $(\mathrm{S})$, boron (B) dan molibdenum (Mo) terbukti dapat secara aktif diserap oleh hifa cendawan dan ditransportasikan ke tanaman inang (Peterson et al. 2004). Tanaman yang memiliki pertumbuhan yang baik lebih tahan terhadap penyakit bercak ungu. Tanaman bermikoriza menjadi lebih vigor, dinding sel lebih tebal dan lebih keras karena keberadaan akumulasi senyawa fenol dan fitoaleksin yang berperan penting dalam menginduksi ketahanan tanaman inang (Vidhyasekaran 2004). CMA juga diketahui dapat meningkatkan akumulasi asam salisilat pada tanaman (Ludwig-Miiller 2000). Asam salisilat merupakan salah satu fitohormon yang berperan penting dalam mengaktivasi gen-gen ketahanan pada tanaman (Garcia-Garrido dan Ocampo 2002).

Berdasarkan hasil pengamatan yang diperoleh maka CMA dapat meningkatkan pertumbuhan bawang merah. CMA juga mampu menekan intensitas dan laju perkembangan penyakit bercak ungu pada bawang merah. Aplikasi CMA bersamaan dengan pemupukan $\mathrm{N}$, $\mathrm{P}$, dan $\mathrm{K}$ memberikan hasil terbaik dalam pertumbuhan dan kesehatan bawang merah.

\section{UCAPAN TERIMAKASIH}

Ucapan terima kasih disampaikan kepada Fakultas Pertanian UGM atas dukungan dana melalui hibah penelitian Fakultas Pertanian UGM, serta Laboratorium Pengamatan Hama dan Penyakit Tanaman Kedu.

\section{DAFTAR PUSTAKA}

Anas I, Tampubolon JLO. 2004. Media campuran tanah-pasir dan pupuk anorganik untuk memproduksi inokulum cendawan mikoriza arbuskula. Bull Agronomi. 32(1):26-31.

Artursson V, Finlay RD, Jansson JK. 2006. Minireview: interactions between Arbuscular Mycorrhizal Fungi and Bacteria and their Potential for Stimulating Plant Growth. Environ Microbiol. 8(1):110. DOI: https://doi.org/10.1111/j.14622920.2005.00942.x.

Bondansari, Susilo BS. 2011. Pengaruh zeolit dan pupuk kandang terhadap beberapa sifat fisik tanah ultisols dan entisols pada pertanaman kedelai (Glycine max L. Merri). Agronomika. 11(2):122-135.

Brundrett MN, Bougher, Dell B, Grove T, Malayczuk N. 1997. Working with Mycorrhizas in Forestry and Agriculture. Canberra (AU): ACIAR.

Daniels BA, Skipper HD. 1982. Methods for the recovery and quantitative estimation of propagules from soil [Vesicular-arbuscular mycorrhizal fungi]. Di dalam : Schenck NC,editor. Methods and Principle of Mycorrhiza Research. St. Paul (US): APS Pr. Hlm 29-36. 
De La Noval B, Pérez E, Martínez B, León O, Martínezgallardo N, Délano-Frier, J. 2007. Exogenous systemin has a contrasting effect on disease resistance in mycorrhizal tomato (Solanum lycopersicum) plants infected with necrotrophic or hemibiotrophic pathogens. Mycorrhiza. 17:449-460. DOI: https://doi.org/10.1007/ s00572-007-0122-9.

Ficke A, David MG, Seem RC. 2002. Ontogenic resistance and plant diseases management: a case study of grape powdery mildew. Phytopathology. 92(6):671-674. DOI: https://doi. org/10.1094/PHYTO.2002.92.6.671.

Fritz M, Jakobsen I, Lyngkjær M F, ThordalChristensen H, Pons-Kühnemann J. 2006. Arbuscular mycorrhiza reduces susceptibility of tomato to Alternaria solani. Mycorrhiza. 16:413-419. DOI: https://doi. org/10.1007/s00572-006-0051-z.

Garcia-Garrido JM, Ocampo JA. 2002. Regulation of the plant defence response in arbuscular mycorrhizal symbiosis. $\mathbf{J}$ Exp. Bot. 53:1377-1386. DOI: https://doi. org/10.1093/jexbot/53.373.1377.

Gernns H, Alten H, Poehling HM. 2001. Arbuscular mycorrhiza increased the activity of a biotrophic leaf pathogen is a compensation possible?. Mycorrhiza. 11:237-243. DOI: https://doi.org/10.1007/ s005720100128.

Goltapeh MY, Danesh R, Prasad R, Varma A. 2008. Mycorrhizal fungi: what we know and what should we know?. Di dalam: Varma AN, editor. Mycorrhiza. Ed ke-3. Heidelberg (DE): Springer. Hlm. 3-27.

Hidayat A , Rosliani R. 1996. Pengaruh pemupukan N, P dan K pada pertumbuhan dan produksi bawang merah kultivar Sumenep. J Horti. 5(5):39-43.

Ismayanti W, Toekidjo, Hadisutrisno B. 2013. Pertumbuhan dan tanggapan terhadap penyakit karat (Puccinia kuehnii) sembilan klon tebu (Saccharum officinarum 1.) yang diinfeksi jamur mikoriza arbuskula. Vegetalika. 2(4):75-87.

Kormanik PP, Mcgraw AC. 1982. Quantification of vesicular arbuscular mycorrhiza an plant roots. Di dalam : Schenck NC, editor. Methods and Principle of Mycorrhiza Research. St. Paul (US): APS. Hlm 37-46.

Ludwig-Miiller J. 2000. Hormonal balance in plants during colonization by mycorrhizal fungi. Di dalam: Kapulnik Y, Douds DD, editor. Arbuscular Mycorrhizas: Physiology and Function. Dordrecht (NL):Kluwer Academic Pub. Hlm 263285. DOI: https://doi.org/10.1007/978-94017-0776-3_12.

Peterson RL, Massicotte HB, Melville LH. 2004. Mycorrhizas: Anatomy and Cell Biology. Ottawa (CA): NRC Research Pr.

Menge JA, Timmer LW. 1982. Procedures for inoculation of plants with vesiculararbuscular mycorrhizae in the laboratory, greenhouse, and field. Di dalam : Schenck NC, editor. Methods And Principle of Mycorrhiza Research. St. Paul (US): APS. Hlm 59-68.

Raduica, Daniela, Propescu. 2008. Research on the biology, technology and use of shallots (Allium ascalonicum). Hort. Magz. 8:250-257.

Soedomo RP. 2006. Seleksi induk tanaman bawang merah. J Hort. 16(4):269-282.

Sumiati E, Gunawan OS. 2006. Aplikasi pupuk hayati mikoriza untuk meningkatkan efisiensi serapan unsur hara NPK serta pengaruhnya terhadap hasil dan kualitas umbi bawang merah. J Hort.17(1): 34-42.

Suwandi, Rosliani R, Soetiarso TA. 1992. Perbaikan teknologi budi daya bawang merah di dataran medium. J Hort. 7(1):541-549.

Swastiningrum A. 2015. Mekanisme cendawan mikoriza arbuskula dalam menekan perkembangan penyakit karat jingga pada tebu [tesis]. Yogyakarta (ID): Universitas Gadjah Mada.

Van der Plank JE. 1963. Plant Disease: Epidemics and Control. New York (US): Academic Pr.

Vidhyasekaran P. 2004. Concise Encyplopedia of Plant Pathology. New York (US): Imprint of The Haworth Pr. Inc.

Wang B, Qiu YL. 2006. Phylogenetic distribution and evolution of mycorrhizas 
in land plants. Mycorrhiza. 16:299-363. DOI: https://doi.org/10.1007/s00572-0050033-6.

Whipps JM. 2004. Prospects and limitations for mycorrhizas in biocontrol of root pathogens. Can J Bot. 82:1198-1227. DOI: https://doi.org/10.1139/b04-082.

Woudenberg JHC, Truter M, Groenewald, Crous PW. 2014. Large-spored Alternaria pathogens in section Porri disetangled. Studies Mycol. 75:1-47. DOI: https://doi. org/10.1016/j.simyco.2014.07.003.

Yu TEJ-C, Egger KN, Peterson RL. 2001. Ectendomycorrhizal associations characteristics and functions. Mycorrhiza. 11:167-171. DOI: https://doi.org/10.1007/ s005720100110. 